\title{
METASTATIC ADENOCARCINOMA IN OMENTUM IN AN INCARCERATED INGUINAL HERNIA: A CASE REPORT WITH REVIEW OF LITERATURE
}

R. M. Prajapati, S. M. Datey, Rakesh Shishodiya, Vikramaditya Singh, Himanshu Bansal
1. Assistant Professor. Department of General Surgery, Sri Aurobindo Medical College \& Post graduate Institute, Indore.
2. Professor. Department of General Surgery, Sri Aurobindo Medical College \& Post graduate Institute, Indore.
3. Professor. Department of General Surgery, Sri Aurobindo Medical College \& Post graduate Institute, Indore.
4. Resident. Department of General Surgery, Sri Aurobindo Medical College \& Post graduate Institute, Indore.
5. Resident. Department of General Surgery, Sri Aurobindo Medical College \& Post graduate Institute, Indore.

\section{CORRESPONDING AUTHOR:}

Dr. R. M. Prajapati, M. S.

260, Vidyapati Nagar,

Nanakheda, Ujjain (M.P.)

E-mail: gunjan8prajapati@gmail.com

Ph: 00919981627685

\begin{abstract}
Inguinal hernias are common and metastatic deposits of intra abdominal malignancies in the omentum are also common. Detailed review of literature depicts that metastatic deposits in hernial sacs are extremely rare(0.05\%).Although, a secondary deposit in hernial sac and/or hernial content is very rare but this possibility cannot be ruled out without a histopathological examination.

We are presenting a case of a 65year old male with a left sided incarcerated inguinal hernia, in which histopathological examination of the incarcerated omentum revealed deposits of a mucinous adenocarcinoma. This patient came to us with complaints related to hernia and neither had any constitutional symptom, nor any evidence of intra abdominal malignancy on examination and routine investigations.

Case is reported because it highlights the importance of histopathological examination of hernial contents and all hernial sacs, excised at the operation.
\end{abstract}

KEYWORDS: Metastasis, omental, hernia sac, incarcerated inguinal hernia

INTRODUCTION: Rutherford Morrison(1) coined the term "The Abdominal Policeman" referring to greater omentum. Omentum has the unique ability of moving to the area of pathological process and restricting it, from spreading to other parts of abdominal cavity. In this case the incarcerated omentum with secondaries was responsible for the diagnosis of an otherwise unknown intra abdominal malignancy. It was a justification of the term of calling "the omentum a policeman" in a true sense.

Case is reported from Sri Aurobindo Medical College and P.G.Institute ,Indore(India) which is a leading tertiary care centre of Central India. We are presenting this case after review of the literature to emphasize the mandatory histopathological examination of all the postoperative specimens which are removed in operations, as a hidden asymptomatic malignancy was diagnosed by the omental histopathological examination.

Review of literature depicts that metastatic deposits of hernial sac or its contents is not unknown but it is very rare. Nicholson CP et al (2) and Oruc et al (3) state that tumours in the hernial sacs occurred in fewer than $0.5 \%$ of all surgically excised sacs. 
Inguinal hernias are common and secondary deposits in omentum are also very common. There are reports of involvement of the sac with metastatic adenocarcinoma from various organs e.g. stomach, colon and prostate(4,5,6,7,8). Metastatic deposits of incarcerated omentum per se were not reported in the literature reviewed by us.

CASE REPORT: 65 year old male was admitted with an incarcerated inguinal hernia on left side leading to mild discomfort while walking without any feature suggestive of intestinal obstruction, like, vomiting or obstipation. Thorough history and clinical examination did not suggest any systemic abnormality or a malignancy. All investigations were within normal limits.

Patient was operated under spinal anesthesia and the repair of the hernia was done by Mesh hernioplasty. Excised Incarcerated omentum and sac were sent for a histopathological examination.

Histopathological examination revealed mucinous adenocarcinomatous infiltration of the omentum.

Patient was subjected to further investigations of Upper GI endoscopy, Sigmoidoscopy, Abdominal ultrasound and Contrast Enhanced Computerized Tomography, which revealed a mass in the Tail of Pancreas and narrowing of Common Bile Duct with evidence of dilated biliary canaliculi. Upper GI endoscopy and ERCP with stenting of Common Bile Duct was done as the patient developed obstructive jaundice at the end of first post operative week.

However patient did not follow further treatment after being discharged on the request. The clinical scenario is indicative of an Pancreatic malignancy with intraperitoneal spread to omentum.

DISCUSSION: Nicholson CP et al(2) reported a retrospective study of 22816 patients operated for inguinal hernias between 1950 to 1988 in the Mayo Clinic. The study showed that only $15(0.05 \%)$ had metastatic tumours found within their hernias. Metastatic lesions were in the sac and the primary site was in Appendix ,Ovary ,Peritoneum ,Prostate, Pancreas and Rectum In two cases(table no.1) the primary could not be diagnosed. Our case is rare because the omentum with secondary deposits in an inguinal hernia was not reported in such an extensive study and other reviewed literature.

In an Ukrainian study of 2308 patients done by Zinbrysky et al ${ }^{(4)}$ described that only $17(0.07 \%)$ patients had histopathological abnormalities(appendicitis and malignancy) which further confirms that histopathological abnormalities are rare but are not unknown.

An intraabdominal malignancy can spread to omentum or peritoneum of the hernial sac by direct contiguity or by transcoelomic implantation. The Hernial Sac can be involved in three ways namely intrasaccular, saccular and extrasaccular(7). Extrasaccular involvement of sac is by the malignancy of nearby structure for example a malignant inguinal node infiltrating a sac of an inguinal hernia. Saccular is the primary mesothelioma of peritoneum.

Omentum with secondary deposits is intrasaccular involvement as it was in the reported case. Other examples of intrasaccular involvement are malignancies of appendix ,colon and ovary when these organs with malignancy become a content of the hernial $\operatorname{sac}^{(9)}$. In this case the patient came with complaints related of an inguinal hernia. The patient did not have any symptom of the hidden cancer, neither had any finding on physical 
examination, nor any clue of intraabdominal malignancy on routine preoperative investigations which were done for hernia repair.Postoperative diagnosis by histopathological examination was a surprise for the patient, his family and the surgeon. Although this surprise was a blessing in a disguise as it pointed towards a hidden intraabdominal malignancy. Case emphasizes that histopathology of all the specimens removed in operation theatre is mandatory.

ACKNOWLEDGEMENTS: We are thankful to Dr. Vinod Bhandari, ( Chairman, Sri Aurobindo Medical College and P.G.Institute), Dr. S. D. Joshi (Dean) and Dr. P. K. Banerjee (Professor and Head of the Department of Surgery), for giving permission to publish this article.

\section{REFERENCES:}

1. Rutherford Morrison in 1906 in British Journal of Surgery(Br Med J $1: 76 ; 1906$ )

2. Nicholson CP, Donohue JH, Thompson GB, Lewis JE, :A study of metastatic cancer found during inguinal hernia repair. Cancer $1992 ; 69: 3008-11$

3. Oruc MT, Kulah B, Saylam b, Moran M, Albavrak L, Coskun F: An unusual presentation of metastatic gastric cancer found during inguinal hernia repair; Hernia 2002 Jul;6(2):88-90.

4. Zinbryts'ky MM, Arseniuk VV. ; Pathological changes of hernial sac and its contents (Article in Ukranian) :Klin Khir 2008 Mar ;(3): 43-4.

5. Matsumoto $G$, Ise $H$, Ogawa $H$, Suzuki N, Matsuno S: Metastic colon carcinoma found within an inguinal hernia a sac: report of a case.Surg Today;2000;30(1): 74-7 Review PMID:10648089(Pub-Med-indexed for MEDLINE)

6. Han-Ching Lin,Tu-Hao Chang, Ching-Chia Li,Wen-Jeng $\mathrm{Wu}$, Chun-Hsiung Huang :Metastatic Prostate Cancer Found Incidentally during an Inguinal Herniorrhaphy: A case report; JTUA 18:39-41, 2007.

7. Lejars $\mathrm{j}$ :Neoplasmes herniaires et peri herniaires. Gaz de hop Par $1889 ; 62$; 801811

8. Lowenfels AB,Rohman M, Ahmed N, Lefkowitz M, Hernia-sac cancer. Lancet 1969; 1: 651

9. Patel T, Viswanathan S, Jambhekar NA; Metastatic adenocarcinoma presenting as an inguinal hernia: A case report and review of literature; Indian J Pathol Microbiol 2007 Jul; 50 (3):541-2 
Table No1. Metastatic Malignant Lesion Found at Inguinal Hernia Repair (World Literature)Nicholson CP(2) et al

\begin{tabular}{|c|c|c|c|c|c|}
\hline Reference & $\begin{array}{l}\text { Age } \\
\text { (yr) }\end{array}$ & sex & Site of primary & " Additional treatment & $\begin{array}{l}\text { Survival } \\
\text { (mo) }\end{array}$ \\
\hline Yoell & 77 & M & Colon & $\begin{array}{l}\text { Colectomy } 16 \mathrm{mo} \\
\text { previously }\end{array}$ & Unknown \\
\hline Yoell & 61 & $M$ & Unknown & -- & Unknown \\
\hline Yoell & 57 & $\mathrm{~F}$ & Ovary & $\begin{array}{l}\text { Hysterectomy, bilateral } \\
\text { salpingo-oophorectomy } \\
\text { y }\end{array}$ & Unknown \\
\hline Lowenfels & 75 & $\mathrm{~F}$ & $\begin{array}{l}\text { Ovary } \\
\text { (suspected) }\end{array}$ & -- & 5 \\
\hline Lowenfels & 86 & $\mathrm{M}$ & Colon & Colostomy & 2 \\
\hline Lowenfels & 74 & M & Pancreas & - & 5 \\
\hline Lowenfels & 73 & $M$ & Prostate & - & 3 \\
\hline $\begin{array}{l}\text { Goonewardea and } \\
\text { Gallant }\end{array}$ & 56 & M & Pancreas & $\begin{array}{l}\text { Segmental small bowel } \\
\text { resection }\end{array}$ & 1 \\
\hline Roslyn et a1. & 83 & M & $\begin{array}{l}\text { Colon } \\
\text { (suspected) }\end{array}$ & - & Unknown \\
\hline Roslyn et a1. & 64 & $M$ & Rectal & - & 6 \\
\hline Brenner et al. & 63 & M & Mesothelioma & - & Unknown \\
\hline Campbell & 43 & M & Appendix & $\begin{array}{l}\text { Appendectomy, } \\
\text { omentectomy }\end{array}$ & Unknown \\
\hline $\begin{array}{l}\text { Kanzer and } \\
\text { Rosenberg }\end{array}$ & 65 & M & Bladder & - & Unknown \\
\hline Chen & 57 & $\mathrm{M}$ & Unknown & - & 10 \\
\hline Dixon et al. & 66 & M & Ileal carcinoid & $\begin{array}{l}\text { Segmental ileal } \\
\text { resection, } \\
\text { appendectomy }\end{array}$ & Unknown \\
\hline Reference & $\begin{array}{l}\text { Age } \\
\text { (yr) }\end{array}$ & sex & Site of primary & Additional treatment & $\begin{array}{l}\text { Survival } \\
\text { (mo) }\end{array}$ \\
\hline Yoell & 77 & $M$ & Colon & $\begin{array}{l}\text { Colectomy } 16 \text { mo } \\
\text { previously }\end{array}$ & Unknown \\
\hline Yoell & 61 & M & Unknown & -- & Unknown \\
\hline Yoell & 57 & $\mathrm{~F}$ & Ovary & $\begin{array}{l}\text { Hysterectomy, bilateral } \\
\text { salpingo-oophorectom y }\end{array}$ & Unknown \\
\hline Lowenfels & 75 & $\mathrm{~F}$ & $\begin{array}{l}\text { Ovary } \\
\text { (suspected) }\end{array}$ & -- & 5 \\
\hline Lowenfels & 86 & $M$ & Colon & Colostomy & 2 \\
\hline Lowenfels & 74 & $\mathrm{M}$ & Pancreas & - & 5 \\
\hline Lowenfels & 73 & $\mathrm{M}$ & Prostate & - & 3 \\
\hline $\begin{array}{l}\text { Goonewardena and } \\
\text { Gallant }\end{array}$ & 56 & $M$ & Pancreas & $\begin{array}{l}\text { Segmental small bowel } \\
\text { resection }\end{array}$ & 1 \\
\hline Roslyn et a1. & 83 & M & $\begin{array}{l}\text { Colon } \\
\text { (suspected) }\end{array}$ & - & Unknown \\
\hline Roslyn et a1. & 64 & $\mathrm{M}$ & Rectal & - & 6 \\
\hline Brenner et al. & 63 & M & Mesothelioma & - & Unknown \\
\hline Campbell & 43 & $M$ & Appendix & $\begin{array}{l}\text { Appendectomy, } \\
\text { omentectomy }\end{array}$ & Unknown \\
\hline Kanzer and & 65 & $M$ & Bladder & - & Unknown \\
\hline
\end{tabular}


CASE REPORT

\begin{tabular}{|l|l|l|l|l|l|}
\hline Rosenberg & & & & & \\
\hline Chen & 57 & $\mathrm{M}$ & Unknown & - & 10 \\
\hline Dixon et al. & 66 & $\mathrm{M}$ & Ileal carcinoid & $\begin{array}{l}\text { Segmental ileal } \\
\text { resection, } \\
\text { appendectomy }\end{array}$ & Unknown \\
\hline
\end{tabular}

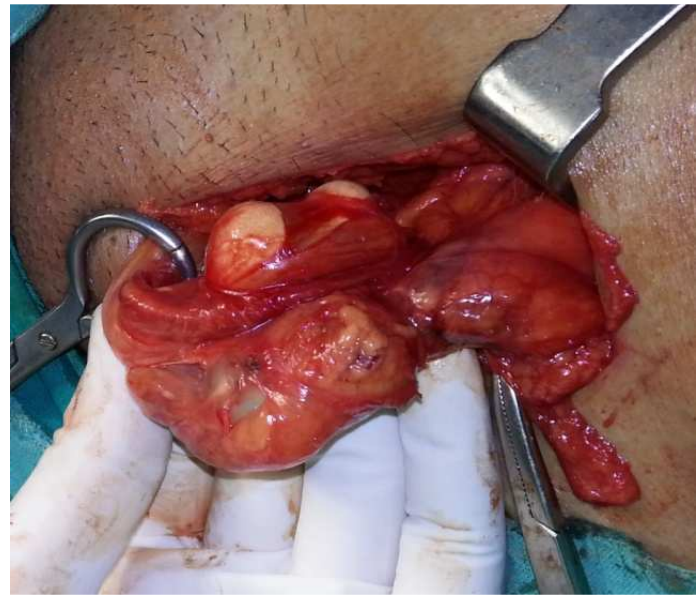

Intra operative photograph showing involved Omentum

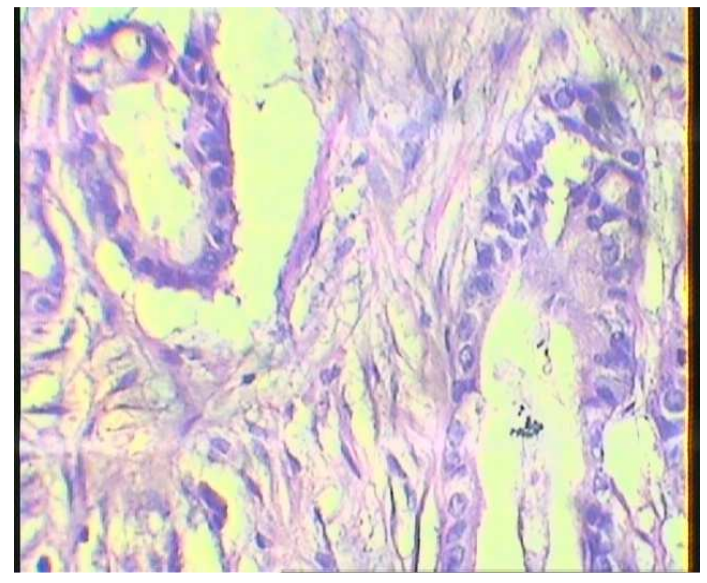

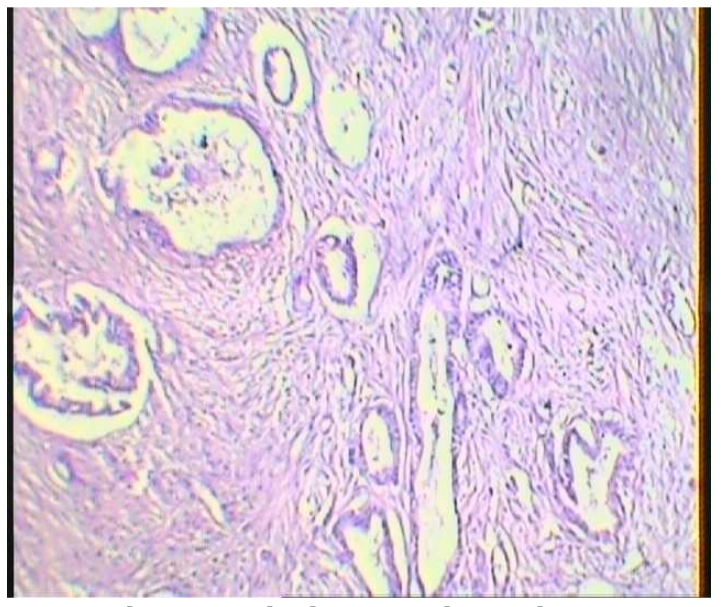

Microphotograph showing the malignant acinar structures infiltrating the fatty tissue of omentum 100x Hematoxilin and eosin stains.

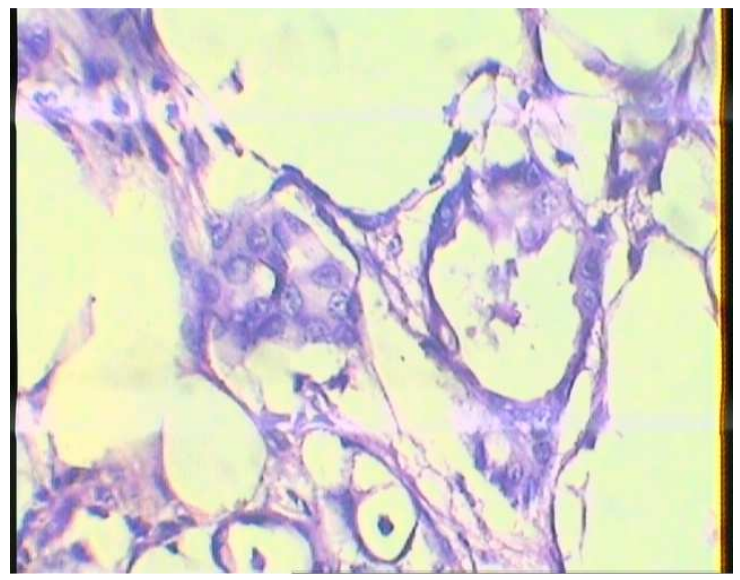

Microphotographs showing the malignant acinar structures infiltrating the fatty tissue of omentum 400x Hematoxylin and Eosin stain 